\title{
A study on qualitative comparison between cryostat and conventional technique for histopathology diagnosis
}

\author{
Zinzala UC. ${ }^{1}$, Goswami AP. ${ }^{2 *}$, Goswami P. ${ }^{3}$, Gondliya J. ${ }^{4}$, Brahmbhatt S. ${ }^{5}$, Khandkar A. ${ }^{6}$ \\ DOI: https://doi.org/10.17511/jopm.2020.i01.10 \\ 1 Umeshkumar C. Zinzala, Postgraduate Resident doctors, Department of Pathology, Government Medical College, Bhavnagar, Gujarat, \\ India. \\ 2* Alpeshpuri P. Goswami, Associate Professor and Laboratory Quality Manager, Department of Pathology, Government Medical College, \\ Bhavnagar, Gujarat, India. \\ 3 Parth Goswami, Assistant Professor, Department of Pathology, Government Medical College, Bhavnagar, Gujarat, India. \\ 4 Jignesh Gondliya, Senior Resident doctor, Department of Pathology, Government Medical College, Bhavnagar, Gujarat, India. \\ 5 Smit Brahmbhatt, Postgraduate Resident doctors, Department of Pathology, Government Medical College, Bhavnagar, Gujarat, India. \\ ${ }^{6}$ Abhijeet Khandkar, Postgraduate Resident doctors, Department of Pathology, Government Medical College, Bhavnagar, Gujarat, India.
}

Introduction: Intraoperative consultation by frozen section technique is an invaluable tool for immediate diagnosis. The correlation of intraoperative frozen section diagnosis with final diagnosis on permanent section is an integral part of quality assurance in surgical pathology. Aims and Objective: Qualitative morphological comparison between frozen section and routine formalin fixed paraffin embedded sections in different tissues, to assess the accuracy of frozen section, to detect the number and type of discrepancies and to assess the causes for discrepancies. Material and Method: The present study retrospectively reviewed frozen sections performed in the pathology department, Sir-t hospital, government medical college, Bhavnagar during a period of 2 year. Diagnostic accuracy of frozen section and its morphological quality and reliability in comparison to histopathology was evaluated by 2 pathologists in a blinded fashion for the following parameters: cellular outline, nuclear and cytoplasmic features, staining pattern and overall morphology. Result: Diagnostic accuracy of frozen section was $95.1 \%$ with false negative case are $4.8 \%$ and no false positive case. Conclusion: Frozen section diagnosis is very useful and highly accurate procedure.

Keywords: Frozen section, histopathology, accuracy, morphological quality

\section{Corresponding Author}

Alpeshpuri P. Goswami, Associate Professor \& Laboratory Quality Manager, Department of Pathology, Government Medical College, Bhavnagar, Gujarat, India.

Email: dralpeshgosai79@gmail.com

\section{How to Cite this Article}

Umeshkumar CZ, Goswami AP, Goswami P, Gondliya J, Brahmbhatt S, Khandkar A. A study on qualitative comparison between cryostat and conventional technique for histopathology diagnosis. Trop J Pathol Microbiol. 2020;6(1):63-68.

Available From

https://pathology.medresearch.in/index.php/jopm/ar ticle/view/415

\section{To Browse}

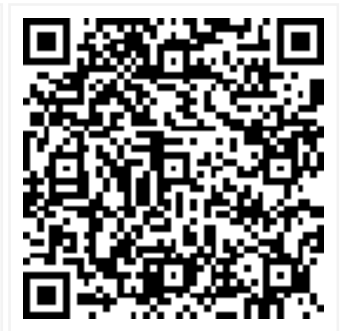

Manuscript Received 08-01-2020

Conflict of Interest No

Review Round 1
$18-01-2020$
Funding
Nil
24-01-2020

Ethical Approval Yes
Review Round 3

Plagiarism X-checker $18 \%$
Accepted 27-01-2020

Note 


\section{Introduction}

Frozen section (FS) technique was first introduced by the eminent pathologist, William $\mathrm{H}$. Welch, from Johns Hopkins Hospital in 1891, and by then frozen section examination has become a routine procedure in most of the hospitals $[1,2]$.

The principle of cutting frozen sections is simple; when the tissue is frozen, the water within the tissue turns into the ice and in this state the tissue is firm, the ice acting as the embedding medium [2].

The indications and limitations of frozen section diagnosis vary in different organs. Diagnostic discrepancies mostly observed in tissue sample from breast, skin, thyroid and uterine cervix [3].

The main purpose of frozen section is to provide rapid diagnosis to guide intra or perioperative patient management.

The indications of frozen section are identification of tissue and unknown pathological processes, evaluation of margins, identification of lymph node metastasis, confirmation of presence of representative samples for paraffin section diagnosis $[3,4,5]$.

A college of American Pathologist (CAP) sponsored review of over $90,000 \mathrm{FS}$ at 461 institutions showed a concordance rate of $98.52 \%$.

The study reasons that the main causes for the discrepancies were either misinterpretation of the original frozen section $(31.8 \%)$, absence of diagnostic tissue in the frozen material but present in the unsampled tissue or in the corresponding permanent section (31.4\%) [4].

The present retrospective study compared the diagnosis of intraoperative FS consultation with the final diagnosis using permanent tissue section and analyze the reasons for discordant diagnosis.

Studies comparing the morphological quality of frozen section and formalin fixed paraffin embedded tissue sections have not been widely reported in literature.

Also, as frozen section is subject to various pitfalls, this study aims to highlight the qualitative morphological comparison between both the techniques, to establish diagnostic accuracy and determine various limitations of frozen section.

\section{Material and Method}

Setting, Duration and type of study: Total 77 tissue samples from 62 cases received for frozen section were included in study. This study was conducted retrospectively over period of 2 year from 2017-19 at Pathology department of Government Medical College, Bhavnagar, Gujrat, India.

Sampling methods: The fresh tissue without any preservative along with requisition form with complete clinical details from the operation theatre was processed for frozen section and same specimen was preserved in formalin for further histopathology examination for correlation.

Exclusion criteria: Inadequate samples, lack of clinical detail/history were excluded from this study.

Data collection procedure: The frozen section diagnoses were compared to that of the permanent sections to assess the accuracy of the technique. Slides of both frozen and routinely processed sections were compared by two pathologists in a blinded fashion for qualitative assessment of morphological details in terms of cellular outline, nuclear and cytoplasmic features, staining pattern and overall morphology.

Data analysis: Data management and Statistical analysis was performed using SPSS software version 21.0. Chi square test was used. The $p$-value $<0.05$ was considered statistically significant.

Scoring system: Each of the five morphological parameters were given a score ranging from 1 to 5 ( $1=$ poor $),(2=$ fair $),(3=$ good $),(4=$ excellent $),(5=$ outstanding). Grading was done by adding the score of each parameter. 5-10 = Poor; 11-15 = Fair; 16$20=$ Good; $21-25=$ Excellent; $>25=$ Outstanding [6].

\section{Result}

Total 62 cases were studied by frozen section method and routine formalin fixed paraffin section method (routine H\&E stain) and comparison were made.

The overall diagnostic accuracy of frozen section was $95.1 \%$ (59 Cases). The incidence of false negative cases was $4.9 \%$ ( 3 Cases) with no false positive cases were noted. There were not any cases of deferred diagnosis. 
Table-1: Comparative diagnostic accuracy analysis of frozen with permanent sections

\begin{tabular}{|c|c|c|c|c|c|c|c|}
\hline $\begin{array}{l}\text { Sr } \\
\text { No }\end{array}$ & Organ/t & $\begin{array}{c}\text { Total } \\
\text { case } \\
\mathrm{s}\end{array}$ & $\begin{array}{c}\text { Tissue } \\
\text { receiv } \\
\text { ed }\end{array}$ & $\begin{array}{l}\text { Consisten } \\
\text { ce } \\
\text { diagnosis }\end{array}$ & $\begin{array}{c}\text { Discord } \\
\text { ant } \\
\text { result }\end{array}$ & $\begin{array}{c}\text { False } \\
\text { positive } \\
\text { diagnosis }\end{array}$ & $\begin{array}{c}\text { False } \\
\text { negative } \\
\text { diagnosis }\end{array}$ \\
\hline 1 & $\begin{array}{l}\text { Oral } \\
\text { cavity }\end{array}$ & 28 & 33 & 27 & 01 & -- & 01 \\
\hline 2 & \begin{tabular}{|l} 
Skin and \\
soft \\
tissue
\end{tabular} & 07 & 09 & 07 & -- & -- & -- \\
\hline 3 & Thyroid & 15 & 15 & 14 & 01 & - & 01 \\
\hline 4 & $\begin{array}{l}\text { Lymph } \\
\text { node }\end{array}$ & 06 & 08 & 05 & 01 & -- & 01 \\
\hline 5 & $\begin{array}{l}\text { Salivary } \\
\text { gland }\end{array}$ & 06 & 06 & 06 & - & -- & - \\
\hline & Total & 62 & 77 & $59(95.1 \%)$ & 03(4.9\% & -- & $03(4.9 \%)$ \\
\hline
\end{tabular}

Table-2: False negative cases observed during this study

\begin{tabular}{|l|l|l|l|}
\hline No & $\begin{array}{c}\text { Organ/tiss } \\
\text { ue }\end{array}$ & \multicolumn{1}{|c|}{ Frozen section diagnosis } & \multicolumn{1}{|c|}{$\begin{array}{c}\text { Paraffin section } \\
\text { diagnosis }\end{array}$} \\
\hline 1 & Thyroid & Multinodular goitre & Follicular hyperplasia \\
\hline 2 & Tongue & $\begin{array}{l}\text { Acute inflammatory ulcerative } \\
\text { lesion }\end{array}$ & Verrucous carcinoma \\
\hline 3 & Lymph node & Reactive lymphadenitis & $\begin{array}{l}\text { Tuberculous } \\
\text { lymphadenitis }\end{array}$ \\
\hline
\end{tabular}

\section{Discussion}

Frozen sectioning is a multistep process involving surgical resection, intraoperative preparation of slides and their microscopic examination, communicating FS diagnoses to surgeon and processing the remaining tissue for further workup. Errors may occur due to problems in any of the steps [7]. Interpretation errors may result from artifacts of the freezing procedure and rarity of the lesion or the inexperience on the part of the pathologist $[8,9,10]$. Many published studies have confirmed the overall diagnostic accuracy of frozen section examination and serves as an integral part of quality assurance [9]. Many studies have mentioned about taking multiple bits from different areas of a lesion and using smear/squash cytological technique along with the frozen section to reduce the error [11]. Frozen section is generally considered an accurate and reliable mode of diagnosis to assist the surgeon on the surgical procedure performed during the surgery itself. However, it is costly and technically limited; and thus available only in major hospitals that house sufficient staff who have the technical knowledge,
Skill and adequate equipment to perform the service. Frozen section is also more difficult to interpret than examination of paraffin-embedded sections. The procedure itself, even in the best hands of the medical laboratory technician, makes the lesion appear worse than a paraffin section of the fixed tissue would. Thus, a good and competent pathologist should know what to expect, what to look for and make a reasonable conclusion without being overtly "clever" [12]. The most common indication for frozen section in the present study was to determine presence/typing of neoplasm to rule out malignancy (61.2\%) followed by assessment of margins (35.6\%) and detection of lymph node metastasis (3.2\%) which was also seen in other studies done (Table 3). Presence/typing of neoplasms is important to operating surgeon, as this will decide the type of operative procedure or further sampling.

Table-3: Comparative studies of indication of frozen section

\begin{tabular}{|c|c|c|c|c|}
\hline \multirow[t]{2}{*}{ Authors } & \multicolumn{4}{|c|}{ Indication } \\
\hline & $\begin{array}{l}\text { Presence/typing } \\
\text { of neoplasm }\end{array}$ & $\begin{array}{l}\text { Assessment } \\
\text { of margin }\end{array}$ & $\begin{array}{l}\text { Identificati } \\
\text { on of cell }\end{array}$ & $\begin{array}{l}\text { Assessment of } \\
\text { nodal status }\end{array}$ \\
\hline $\begin{array}{l}\text { Roy S et al., } \\
{[7]}\end{array}$ & $65.9 \%$ & $30.6 \%$ & -- & $3.8 \%$ \\
\hline $\begin{array}{l}\text { Patil P et al., } \\
{[12]}\end{array}$ & $55 \%$ & $34 \%$ & -- & $11 \%$ \\
\hline $\begin{array}{l}\text { Chbani L et al., } \\
{[14]}\end{array}$ & $85.4 \%$ & $7.3 \%$ & $4.3 \%$ & -- \\
\hline $\begin{array}{l}\text { White } V \text { et al., } \\
{[15]}\end{array}$ & $41 \%$ & $26 \%$ & -- & $28 \%$ \\
\hline $\begin{array}{l}\text { Saumaya misra } \\
\text { et al., (16) }\end{array}$ & $84.6 \%$ & $13.5 \%$ & $1.9 \%$ & -- \\
\hline Present study & $61.2 \%$ & $35.6 \%$ & -- & $3.2 \%$ \\
\hline
\end{tabular}

Table-4: Different Studies illustrating limitations observed during FS

\begin{tabular}{|l|l|l|l|l|l|}
\hline \multicolumn{1}{|c|}{ Authors } & \multirow{2}{*}{\begin{tabular}{l} 
No of \\
\cline { 3 - 6 }
\end{tabular}} & \multicolumn{5}{|c|}{$\begin{array}{l}\text { limitation } \\
\text { errors (\%) }\end{array}$} & $\begin{array}{l}\text { Sampling } \\
\text { errors (\%) }\end{array}$ & $\begin{array}{l}\text { interpretation } \\
\text { errors (\%) }\end{array}$ & $\begin{array}{l}\text { lack of clinical } \\
\text { details (\%) }\end{array}$ \\
\hline $\begin{array}{l}\text { Patil P et al., } \\
{[12]}\end{array}$ & $3 / 100$ & -- & $1.0 \%$ & $2.0 \%$ & -- \\
\hline $\begin{array}{l}\text { Saumaya } \\
\text { misra et al., } \\
(16)\end{array}$ & $12 / 52$ & $23.07 \%$ & $1.92 \%$ & $1.92 \%$ & $3.84 \%$ \\
\hline $\begin{array}{l}\text { Mahe E et al., } \\
{[17]}\end{array}$ & $17 / 81$ & $0.12 \%$ & $0.6 \%$ & $1.5 \%$ & -- \\
\hline $\begin{array}{l}\text { Evans CA et } \\
\text { al., [18] }\end{array}$ & $3 / 240$ & -- & $0.4 \%$ & $0.8 \%$ & - \\
\hline Present study & $06 / 62$ & $9.7 \%$ & $3.2 \%$ & $1.6 \%$ & - \\
\hline
\end{tabular}

Also, margin clearance of a malignant lesion is 
Crucial as tumor recurrence can be aggressive and difficult to treat [13]. Quality of prepared sections during cryostat sectioning plays an important role in FS diagnoses. Technical issues leading to alteration in cytological or architectural features necessary for establishing accurate diagnoses during processing of frozen sectioning may pose difficulty. However, use of frozen section with limitations in mind make it a highly sensitive and specific technique playing critical role in management of patients [16].

In thyroid, one case was false negatively diagnosed as a multinodular goitre on frozen section which later on diagnosed as a follicular hyperplasia by routine paraffin section. This discrepancy was mainly due to technical error mainly due to freezing artifact. The limitations mentioned by Hwang et al and Anton RC et al in frozen section evaluation of thyroid are sampling and freezing artefact [19]. Ground glass appearance of the nuclei as an artifact produced during formalin fixation is a diagnostic feature which is not present in frozen section and alcohol fixed smears. Studies have also confirmed that it is as difficult to differentiate benign from malignant follicular lesions at the time of frozen section. Entire capsule must be submitted for the microscopic examination which could be time consuming and less productive at the time of frozen section. Frozen section distorts and collapses blood vessels resulting in a difficult task to locate angioinvasion. Literature have mentioned that the angioinvasion and the capsular invasion are best assessed on permanent histological sections. Frozen section evaluation of thyroid lesion may sometimes be challenging and has limited utility and has caused the greatest number of diagnostic disagreements, largely related to presence/typing of a neoplasm [19]. However, gross inspection, complemented by cytological and histological review, provides the surgeons with the rapid, reliable and cost-effective information necessary for optimum patient care $[19,20]$.

One case of verrucos carcinoma of tongue was false negatively diagnosed on frozen section as a acute inflammatory ulcerative lesion due to sampling error wherein section was taken from the ulcerated area instead of taking it from the margin of the lesion. One case of tuberculous lymphadenitis was false negatively diagnosed as a reactive lymphadenitis due to interpretational error.

Many studies (Table-4) have concluded that disagreements in FS diagnosis are mostly due to interpretative and sampling errors, followed by
Sectioning, inadequate history, staining and labelling [4]. Most frequent limitation observed in present study were technical error $(9.7 \%)$ followed by sampling error $(3.2 \%)$ and interpretational error $(1.6 \%)$. Interpretational errors resulting from technical artifacts like freezing procedure or sectioning are avoidable and can be overcome by experience of the pathologist [21].

In other site such as retroperitonium, salivary gland, hepatobiliary, stomach and bowel and pancreas, frozen section was sent for primary diagnosis, margin assessment and nodal metastasis. Benign and malignant lesions were identified correctly in most of the cases, but typing error was a frequent problem. This was due to loss of architectural pattern and freezing artifact.

Many authors believe that determining the presence of malignancy without subtyping or a judicious deferral can be the best option to decrease the discrepancies [18]. Many authors believe that determining the presence of malignancy without subtyping or a judicious deferral can be the best option to decrease the discrepancies [19].

CAP specifies that TAT in frozen section reporting should be completed within 20 minutes in $90 \%$ or else analysis of outliers should be done. The average turnaround time in the present study was 20 minutes with 54 cases reported within 20 minutes or less and was comparable with other studies $[3,4,13]$.

Limitation of Study: Less sample size was the limitation of this study.

\section{Conclusion}

Frozen section diagnosis is very useful and highly accurate procedure. Various limitations encountered in the present study were error in interpretation due to freezing artifact causing distortion of morphological features which occurs due to variation in freezing temperature and time with different types of tissues, inadequate clinical and operative details and lack of orientation leading to sampling error. Avoiding technical errors in sectioning and staining, sampling by pathologist, frozen complemented with cytological and histological review and intimal cooperation with surgeon, good communication between surgeon and pathologist can avoid certain limitations and provide rapid, reliable, cost effective information necessary for proper diagnosis and optimum patient care. 


\section{What the study adds to the existing knowledge?}

Avoiding technical errors in sectioning and staining, combination of knowledge about clinical presentation can reduce the limitations and provide rapid, reliable and cost-effective details necessary for rapid diagnosis and on table patient management.

\section{Author's Contribution}

Dr. Umeshkumar C. Zinzala: Provision of study materials or patients, Statistical expertise, Collection, Analysis and interpretation of the data

Dr. Alpeshpuri P. Goswami: Conception and design, Analysis and interpretation of the data, Drafting of the article, Final approval of the article, Administrative, technical, or logistic support, Critical revision of the article for important intellectual content

Dr. Smit Brahmbhatt: Statistical expertise, Collection and assembly of data.

Dr. Abhijeet Khandkar: Collection, Analysis and interpretation of the data

Dr. Jignesh Gondliya: Provision of study materials or patients, Statistical expertise, Collection and assembly of data

Dr. Parth Goswami: Critical revision of the article for important intellectual content, Collection and assembly of data.

\section{Reference}

01. Folkerth RD. Smears and frozen sections in the intraoperative diagnosis of central nervous system lesions. Neurosurgery Clinic North Am. $1994 ; 5(1) 1-8$.

[Crossref]

02. Özdamar S, Bahadir B, Ekem T, Kertis G, Gün B, Numanoðlu G. Frozen section experience with emphasis on reasons for discordance. Turk J Cancer. 2006;36(4)157-161.

[Crossref]

03. Gephardt GN, Zarbo RJ. International comparison of Frozen section consultation, A college of American Pathologists Q-probe study of 90,538 cases in 461 institutions. Arch Pathol Lab Med. 1996;120(9)804-809.

[Crossref]
04. Rosai \& Ackerman. Surgical Pathology, Introduction. 10th ed, India- Elsevier. 2011,p112.

[Crossref]

05. Tripathi M, Bansal R, Gupta M, Bharat V. Comparison of routine fixation of tissues with rapid tissue fixation. J Clinic Diagnos Res- JCDR. 2013;7(12)2768.

doi:

[Article:https://doi.org/10.7860/JCDR/2013/6233.37 54][Crossref]

06. Roy S, Parwani AV, Dhir R, Yousem SA, Kelly $S M$, Pantanowitz L. Frozen section diagnosis- is there discordance between what pathologists say and what surgeons hear?. Am J Clinic Pathol. 2013;140(3)363-369.

doi:

[Article:https://doi.org/10.1309/AJCPHUE5ENZDU4D] ][Crossref]

07. Nigrisoli E, Gardini G. Quality control of intraoperative diagnosis, annual review of 1490 frozen sections. Pathol. 1994;86(2)191-195.

[Crossref]

08. White VA, Trotter MJ. Intraoperative consultation/final diagnosis correlationrelationship to tissue type and pathologic process. Arch Pathol Lab Med. 2008;132(1)2936.

doi: [Article:https://doi.org/10.1043/15432165(2008)132[29:IFDCRT]2.0.CO;2][Crossref]

09. Laucirica R. Intraoperative assessment of the breast- guidelines and potential pitfalls. Arch Pathol Lab Med. 2005;129(12)1565-1574.

doi: [Article:https://doi.org/10.1043/15432165(2005)129[1565:IAOTBG]2.0.CO;2][Crossref]

10. Patil P, Shukla S, Bhake A, Hiwale K. Accuracy of frozen section analysis in correlation with surgical pathology diagnosis. Int J Res Med Sci. 2015;3(2)399-404.

doi:[Article:https://doi.org/10.5455/2320-6012. ijrms20150203][Crossref]

11. Chandramouleeswari K, Yogambal M, Arunalatha P, Bose JC, Rajendran A. Frozen and paraffin sections-Comparative study highlighting the concordance and discordance rates in a tertiary care centre. IOSR J Dent Med Sci. $2013 ; 12(5) 26-30$.

[Crossref] 
12. Jaafar $H$. Intra-operative frozen section consultation- concepts, applications and limitations. Malays J Med Sci MJMS. 2006;13(1)4-12.

[Crossref]

13. Hull ME, Hunphrey PA, Pfeifer JD. Washington Manual of surgical pathology. 1st ed; Elsevier. 2006- chapter 51.

[Crossref]

14. Chbani L, Mohamed S, Harmouch T, El Fatemi $H$, Amarti A. Quality assessment of intraoperative frozen sections- An analysis of 261 consecutive cases in a resource limited area-Morocco. Health. 2012;4(7)433-435.

doi:[Article:http://dx.doi.org/10.4236/health.2012. 47068][Crossref]

15. Jerome BT. Frozen section and surgical pathologist. Arch Pathol Lab Med. 2009;133(7)1135-1138.

doi: [Article:https://doi.org/10.1043/1543-2165133.7.1135][Crossref]

16. Mahe E, Ara S, Bishara M, Kurian A, Tauqir S, Ursani $N$, et al. Intraoperative pathology consultation- error, cause and impact. Canadian J Surg. 2013;56(3)E13-E18.

doi: [Article:https://doi.org/10.1503/cjs.011112] [Crossref]
17. Mishra S, Gupta M, Bharat V, Bansal R. Qualitative Comparative Study of Frozen Section with Routine Histological Technique. Nat J Lab Med. 2016;2;44-50.

[Crossref]

18. Evans CA, Suvarna SK. Intraoperative diagnosis using the frozen section technique. J Clinic Pathol. 2006;59(3)334.

[Crossref]

19. Anton RC, Wheeler TM. Frozen section of thyroid and parathyroid specimens. Arch Pathol Lab Med. 2005;129(12)1575-1584.

doi: [Article:https://doi.org/10.1043/15432165(2005)129[1575:FSOTAP]2.0.CO;2][Crossref]

20. Chi JG, Park SH. An evaluation of frozen section biopsy in 4434 cases. J Kor Med Sci. $1987 ; 2(4) 239-245$.

doi:

[Article:https://dx.doi.org/10.3346\%2Fjkms.1987.2. 4.239][Crossref]

21. Rogers C, Klatt EC, Chandrasoma PA. Accuracy of frozen-section diagnosis in a teaching hospital. Arch Pathol Lab Med. 1987;111(6)514517.

[Crossref] 